\title{
ANALISIS PENERAPAN METODE TRANSMITTER RECEIVER UNIT (TRU) UPGRADING UNTUK MENGATASI TRAFFIC CONGESTION JARINGAN GSM PADA BTS AREA PURWOKERTO KOTA
}

\author{
Alfin Hikmaturokhman ${ }^{1}$, Eka Wahyudi ${ }^{2}$, Yunita Trias Susanti ${ }^{3}$ \\ Program Studi Diploma III Teknik Telekomunikasi, purwokerto \\ Akademi Teknik Telekomunikasi Sandhy Putra Purwokerto \\ ${ }^{1}$ Alfin_h21@yahoo.com, ${ }^{2}$ ekawahyudi@akatelsp.ac.id, ${ }^{3}$ nyiet_belle_19@yahoo.com
}

\begin{abstract}
ABSTRAK
Semakin banyaknya pengguna selular maka akan semakin banyak trafik yang akan tertampung. Trafik yang melebihi kapasitas kanal yang disediakan dapat menyebabkan kondisi Traffic Congestion. Untuk menanganinya diperlukan metode penambahan kapasitas kanal agar semua trafik dapat tertampung dengan baik. Metode ini disebut dengan TRU Upgrading. Transmitter Receiver Unit (TRU) adalah hardware yang terletak pada Radio Base Station dalam BTS yang berisi slot-slot kanal sedangkan metode TRU Upgrading adalah metode dengan menambahkan/upgrade kapasitas kanal yang tersedia dari konfigurasi TRU yang telah ada sebelumnya, misalkan pada BTS Pabuaran memiliki konfigurasi $3 \times 2 \times 3$ karena terjadi kejenuhan pelanggan maka konfigurasi TRU diupgrade menjadi $3 \times 4 \times 3$. Perubahan konfigurasi TRU maka merubah konfigurasi BTS-nya serta menambah kapasitas kanalnya. Key Performance Indicator (KPI) yang baik pada Indosat adalah menggunakan batas GoS $2 \%$. Nilai GoS ini dikaitkan dengan tabel Erlang untuk mendapatkan sebuah nilai intensitas trafik. Jika nilai intensitas trafik konfigurasi TRU yang digunakan kurang dari nilai intensitas trafik pelanggan maka disebut traffic congestion. Sebagai akibat dari traffic congestion adalah kondisi blocking. TRU Upgrading ini dilakukan dengan harapan nilai blocking panggilan menjadi $0 \%$. Pada Purwokerto kota, diterapkan TRU Upgrading untuk cell Grendeng 3, Pabuaran 2, dan Unsoed 1 karena trafik pelanggan yang terjadi melebihi nilai intensitas trafik dari konfigurasi TRU yang digunakan. Untuk cell Unsoed 1 dan Grendeng 3 meski telah dilakukan TRU Upgrading menjadi 4 buah TRU tetap terjadi traffic congestion sebesar 8 sampai dengan 15 Erlang dikarenakan pada cell-cell ini mengcover area yang padat penduduk. Sedang untuk Pabuaran 2 penerapan TRU upgrading mencapai keefektifan sebesar 100\%.
\end{abstract}

Kata kunci : Traffic Congestion, TRU Upgrading, blocking, GoS

\section{ABSTRACT}

Increasing the number of mobile users, will cause more traffic can be accommodated. Traffic that exceeds the availability of the channel capacity can cause the Traffic Congestion condition. A method is needed to handle the addition of channel capacity so that all traffic can be accommodated well. This method is called TRU Upgrading. Transmitter Receiver Unit (TRU) is a hardware that placed in Radio Base Station inside BTS which consist of some channels. TRU Upgrading method is a method to add / upgrade the channel capacity that available from TRU configurations that have been placed before, for example the BTS Pabuaran have $3 \times 2 \times 3$ configuration, but due to the saturation of TRU customer it was upgraded into $3 \times 4 \times 3$ configuration. TRU's configuration changing will also change the configuration of base stations and increase the channel capacity. A good Key Performance Indicator (KPI) on Indosat is using GOS 2\%. This GOS value is related with Erlang's tables to get a traffic intensity's value. When the traffic intensity's values that used are less than the intensity's value of customer traffic, it is called traffic congestion. The result of this traffic congestion will make blocking condition. TRU Upgrading was used in condition to reduce the call blocking value became 0\%. At Purwokerto's town area, TRU upgrading were applied on Grendeng 3's cell, Pabuaran 2's cell, and Unsoed 1's cell because of customer traffic that occurs was exceed the traffic intensity values of the current TRU configuration. Although. Unsoed 1's cell and Grendeng 3's cell were applied TRU Upgrading into 4 pieces, but traffic congestion still occurs into 8-15 Erlang because this cells were cover densely populated area. As for Pabuaran 2's cell, this kind of method can achieve $100 \%$ effectiveness.

Key words: Traffic Congestion, TRU Upgrading, blocking, GoS 


\section{PENDAHULUAN}

\subsection{Latar Belakang}

Dengan semakin banyak pengguna telekomunikasi selular di dalam suatu cakupan area maka akan mempengaruhi sistem jaringan telepon yang ada di sekitar daerah tersebut. Apabila jumlah pelanggan dan trafik yang masuk melebihi kapasitas saluran yang disediakan oleh sistem jaringan maka akan menimbulkan traffic congestion, yaitu suatu kondisi dimana sebagian besar panggilan dilakukan dalam waktu yang bersamaan pada salah satu sel tertentu dalam suatu BTS, sehingga mengakibatkan kanal trafik yang tersedia tidak dapat menampung trafik yang masuk dan meningkatkan tingkat probabilitas penolakan panggilan (blocked call) yang akan berpengaruh pada nilai GoS (Grade Of Service) sistem jaringan. Oleh karena itu diperlukan pengaturan trafik pada saluran yang digunakan untuk saluran tersebut agar tidak terjadi traffic congestion. Pengaturan trafik tersebut dapat dilakukan dengan cara menyediakan lebih banyak kanal dalam wilayah cakupan layanan di titik-titik lokasi tertentu. Strategi untuk meningkatkan kapasitas kanal ini ditempuh dengan menerapkan metode TRU (Transmitter Receiver Unit) Upgrading.

TRU Upgrading adalah metode menambahkan perangkat TRU dalam satu sektor BTS. Penambahan perangkat TRU tentu saja dengan memperhitungkan kondisi jaringan dan perilaku pelanggan. Metode TRU Upgrading ini diharapkan dapat meningkatkan kapasitas sel (memecah tingkat kejenuhan trafik pada sel tertentu dalam salah satu BTS). Atau dengan kata lain metode TRU Upgrading diterapkan agar penanganan traffic congestion dapat dilakukan secara efektif.

\subsection{Rumusan Masalah}

Permasalahan yang dapat dikaji yaitu:

1. Berapa besar traffik congestion yang terjadi di area Purwokerto kota dan sektor mana saja di BTS area Purwokerto kota yang perlu diterapkan TRU Upgrading?

2. Bagaimana desain TRU pada masing-masing BTS area Purwokerto kota?

3. Seberapa besar pengaruh metode TRU Upgrading untuk menangani traffic congestion pada area Purwokerto kota?

\subsection{Tujuan Penulisan}

Tujuan dari penulisan Tugas Akhir ini adalah:

1. Mengetahui cara mengatasi dan meminimalisir traffic congestion dengan menerapkan metode TRU Upgrading.

2. Mengetahui seberapa besar pengaruh penerapan metode TRU Upgrading untuk mengatasi traffic congestion.

\subsection{Manfaat Penulisan}

Manfaat dari penulisan Tugas Akhir dengan topik ini adalah menjadi acuan dan masukan tentang solusi yang dapat diterapkan untuk mengatasi traffic congestion yang disebabkan karena traffic overload pada BTS jaringan GSM. 


\subsection{Batasan Masalah}

Pembahasan dalam Tugas Akhir ini dibatasi pada beberapa masalah, diantaranya:

1. Teknologi yang diteliti merupakan teknologi sistem selular GSM 900.

2. Penelitian ini hanya membahas metode TRU Upgrading.

3. Penelitian ini hanya membahas pada media suara.

4. Penelitian ini TCH/Half Rate.

5. Hanya membahas site Grendeng, Unsoed, dan Pabuaran yang sedang mengalami Traffic Congestion pada PT Indosat,Tbk.

6. Adapun parameter penelitian yang akan dianalisa pada jaringan GSM 900 PT. Indosat,Tbk Purwokerto antara lain Daily Traffic, Traffic Channel (TCH) Block, konfigurasi pengkanalan.

7. Analisa hasil perhitungan menggunakan Microsoft excel 2007.

\subsection{Desain Penelitian}

1. Metode penelitian

- Studi Kasus

Studi kasus dilakukan dengan mengumpulkan data-data lapangan terhadap BTS area Purwokerto kota PT. Indosat Tbk, Purwokerto.

- Studi Pustaka

Studi pustaka dilakukan dengan mempelajari hal - hal yang terkait dengan traffic overload, traffic congestion dan metode TRU Upgrading.
Hal ini dimaksudkan untuk lebih memahami masalah yang akan dibahas.

- Wawancara

Wawancara dilakukan dengan melakukan tanya jawab dengan pembimbing lapangan yang lebih memahami masalah tersebut, serta melakukan konsultasi dengan dosen pembimbing Tugas Akhir mengenai perkembangan Tugas Akhir yang dikerjakan

2. Instrumen penelitian

Instrumen penelitian yang digunakan Daily Traffic, Traffic Channel (TCH) Block, konfigurasi pengkanalan serta menggunakan Microsoft Excel dalam pengolahan data.

3. Metode pengumpulan data

Dalam penelitian ini data yang digunakan data sekunder yaitu data standar kinerja yang diambil adalah kinerja parameter Call Success Rate (CSR), Daily Traffic, Traffic Channel (TCH) Block.

4. Variabel penelitian

Variabel penelitian yang akan diamati diantaranya, jumlah saluran (n saluran), intensitas trafik (Erlang), probabilitas blocking / GoS (Grade of Service), volume trafik, dan konfigurasi BTS.

5. Metode analisa

Metode analisa dilakukan dengan melihat dan menganalisa perubahan pada parameter sebelum dan sesudah dilakukan TRU upgrading. 


\section{KAJIAN TEORI}

\subsection{Arsitektur Jaringan GSM}

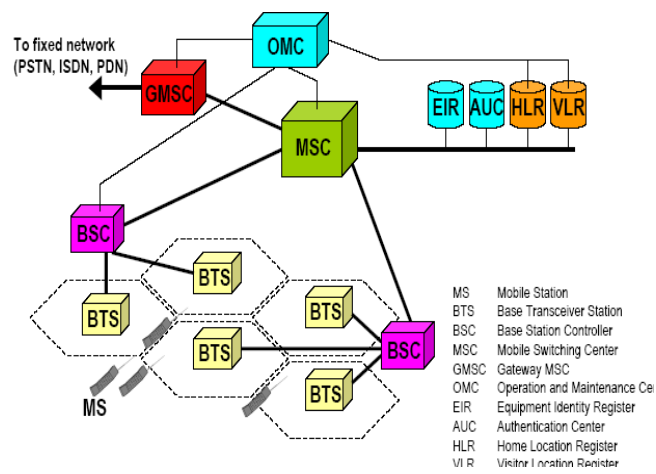

Gambar 1. Arsitektur GSM

Jaringan selular memiliki arsitektur yang terdiri dari tiga subsistem yang saling berinteraksi dan terkoneksi. Masing-masing subsistem ini adalah Base Station Subsystem (BSS), Network Switching Subsystem (NSS), dan Operation Suport Subsystem (OSS). Mobile System (MS) juga merupakan sebuah subsistem, namun biasanya dari segi arsitektur dipandang sebagai bagian dari BSS. Mobile Station (MS) yang berfungsi sebagai transmit dan receive, Base Station Subsystem (BSS) yang merupakan bagian dari jaringan yang menyediakan interkoneksi (interface) dari MS ke peralatan dasar switching terdiri dari BTS dan BSC, dan Network Switching System (NSS) dan Network Management System (NMS) yang mengatur dan memanajeman untuk operasi dan perawatan didalam jaringan pada OMC yang bertanggung jawab pada pengaturan jaringan.

\subsection{Struktur kanal GSM}

Global System for Mobile Communication (GSM) menggunakan metode akses Time Division Multiple Access (TDMA). Dalam Akses
Time Division Multiple Access (TDMA) setiap frame Time Division Multiple Access (TDMA) dibagi menjadi kanal-kanal yang berfungsi sebagai media sehingga informasi dapat ditransmisikan.

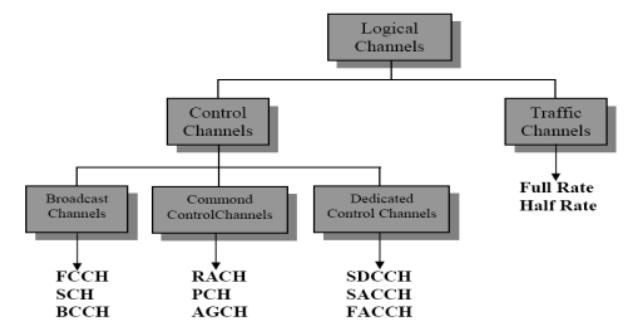

Gambar 2. Struktur Kanal GSM

\subsection{Traffic Congestion}

Secara umum trafik dapat diartikan sebagai perpindahan informasi dari satu tempat ke tempat lain melalui jaringan telekomunikasi. Besaran dari suatu trafik telekomunikasi diukur dengan satuan waktu, sedangkan nilai trafik dari suatu kanal adalah lamanya waktu pendudukan pada kanal tersebut. Salah satu tujuan perhitungan trafik adalah untuk mengetahui unjuk kerja jaringan (Network Performance) dan mutu pelayanan jaringan telekomunikasi (Quality of Service).

Traffic Congestion adalah situasi atau keadaan tersendatnya atau bahkan terhentinya lalu lintas informasi yang disebabkan oleh banyaknya jumlah pelanggan melebihi kapasitas kanal. Traffic Congestion terjadi saat trafik yang masuk pada jaringan tidak dapat diteruskan karena keterbatasan kanal. Ada beberapa jumlah keadaan yang menyebabkan kebuntutan penyampaian informasi, yaitu kebanyakan penyedia jasa telepon mengurangi kapasitas 
kanal pada titik yang ditentukan atau meningkatnya jumlah pelanggan.

\subsection{Radio Base Station}

Radio Base Station termasuk dalam bagian BTS. Unit - unit RBS terbagi menjadi 5 bagian yaitu Distribution Switch Unit (DXU), Transmitter Receiver Unit (TRU), Combining and Distribution Unit (CDU), Energy Control Unit (ECU), Power Supply Units (PSUs)

\section{Distribution Switch Unit (DXU)}

Adalah sentral kontrol unit dari RBS. Terdapat satu DXU pada setiap RBS. DXU menyediakan interface time slot ke tranceiver yang sudah ditentukan. Fungsi-fungsi dari DXU adalah sebagai interface dan mengontrol link ke BSC, memeriksa beberapa waktu untuk komunikasi dari MS ke BTS, sebagai alarm apabila terjadi masalah pada perangkat yang terhubung, dan menyimpan database konfigurasi cabinet yang terhubung dengannya.

\section{Transmitter Receiver Unit (TRU)}

Adalah unit transmitter/receiver dan sinyal processing yang memancarkan dan menerima sinyal radio frekuensi yang dilewatkan dari dan menuju MS. Setiap TRU menangani 8 timeslot. TRU memiliki satu output transmit dan dua inlet penerima. Fungsi - fungsi dari TRU adalah sebagai perangkat penerima dan pengiriman sinyal, pemroses sinyal pada media suara.

3. Combining and Distribution Unit (CDU) adalah interface antara TRU dan antena. Tujuan utama CDU adala untuk mengurangi jumlah penggunaan antena dalam setiap cell atau sector. Fungsi-fungsi dari CDU adalah sebagi pembangunan perangkat transmitter, memfilter sinyal yang diterima oleh receiver.

\section{Energy Control Unit (ECU)} adalah unit yang mengkontrol dan mengawasi daya pada perangkat dan untuk mengatur sehu dan kondisi didalam cabinet untuk memelihara sistem operasi.

\section{Power Supply Units (PSUs) \\ adalah unit yang berfungsi yang} menyearahkan tegangan $\mathrm{AC}$ yang masuk untuk diubah menjadi +24 VCD yang dibutuhkan untuk sistem internal distribution. Output dari PSUs sbenarnya adalah sebesar +27,2 VCD karena untuk menghindari power yang lebih rendah dari muatan digunakan sebagai daya trafik yang tinggi dan pengisian ulang baterai dalam waktu bersamaan. Ada juga jenis PSU yang berfungsi menyearahkan tegangan AC yang masuk untuk diubah menjadi -48 VCD digunakan untuk indoor cabinet yang di instalasi.

\subsection{TRU Upgrading}

Metode ini dilakukan dengan cara menambahkan perangkat TRU baru. Penambahan perangkat TRU artinya menambahkan jumlah kanal, semakin banyak jumlah kanal maka makin teratasi traffic congestion yang terjadi. Sedikit ulasan mengenai langkah-langkah TRU Upgrading yang 
dilakukan untuk menambah kapasitas BTS, yaitu:

1. Pengecekan kondisi trafik (selama \pm 2 minggu),

2. Pengecekan konfigurasi BTS,

3. Pengecekan kapasitas manajemen untuk menentukan butuh di-upgrade atau tidak (dilihat dari trafik dan kapasitas BTS)

4. Jika dibutuhkan, langsung dilakukan TRU Upgrading.

\section{ANALISA DAN PEMBAHASAN}

Analisis dan pembahasan pada tugas akhir ini adalah berdasarkan perbandingan nilai parameter-parameter performansi cell sebelum dan sesudah dilakukan TRU Upgrading.

Tabel 1. KPI PT. Indosat, Tbk Purwokerto

\begin{tabular}{|c|c|c|c|c|}
\hline $\begin{array}{l}\text { Performan } \\
\text { si (dalam } \\
\text { kondisi) }\end{array}$ & $\begin{array}{l}\text { GoS } \\
(\%)\end{array}$ & $\begin{array}{c}\text { Call } \\
\text { Success } \\
\text { Rate }(\%)\end{array}$ & $\begin{array}{c}\text { Drop } \\
\text { Call } \\
\text { Rate } \\
(\%)\end{array}$ & $\begin{array}{c}\text { Offered } \\
\text { traffic }= \\
\text { carrried } \\
\text { traffic + } \\
\text { blocked } \\
\text { traffic }\end{array}$ \\
\hline Baik & $<1$ & $>93.0$ & $<1$ & $>$ \\
\hline Normal & $\begin{array}{l}1.0- \\
2.0\end{array}$ & $90.0-93.0$ & $1.0-2.0$ & $=$ \\
\hline Buruk & $>2$ & $<90.0$ & $>2$ & $<$ \\
\hline
\end{tabular}

Waktu pelaksanaan implementasi TRU

Upgrading pada cell yang terjadi congest dilakukan pada waktu yang bersamaan yaitu tanggal 24 April 2011 pukul 00.00 WIB. Standar KPI dari PT. Indosat, Tbk Purwokerto dapat dilihat pada tabel 1 .

\subsection{Kondisi TCH Normal TRU}

Konfigurasi BTS menunjukan banyaknya jumlah TRU yang dipasang pada tiap-tiap cellnya. Misalkan konfigurasinya adalah $4 \times 3 \times 2$ maka dalam BTS tersebut terpasang 4 TRU dalam satu cell dan 3 TRU serta 2 TRU untuk cell-cell lainnya. Modul TRU yang biasa digunakan oleh GSM maksimal sebanyak 4 buah, dan jarang digunakan konfigurasi cell dengan 1 modul TRU saja (TRU yang digunakan Indosat adalah perangkat tipe Nokia Ultrasite yang mana 1 buah TRU sama dengan 1 TRX). Beragamnya konfigurasi TRU yang digunakan disesuaikan dengan kebutuhan pelanggan, karena banyaknya perangkat TRU yang digunakan mempengaruhi nilai trafik pelanggan yang ditampung.

Asumsi konfigurasi BTS pada cell yang menggunakan 2 TRU sebagai berikut :

$$
\begin{aligned}
& 1 \mathrm{TRU}=8 \text { timeslot } \\
& 2 \mathrm{TRU}=2 \times 8 \text { timeslot } \\
&=16 \text { timeslot } \rightarrow \\
& 14 \mathrm{TCH} \\
& 1 \mathrm{BCCH} \\
& 1 \mathrm{SDCCH}
\end{aligned}
$$

\section{$1 \mathrm{SDCCH}$}

Terdapat 16 timeslote atau kanal ini terbagi 1 kanal untuk BCCH. Kanal BCCH ini berfungsi untuk menyiarkan daftar kanal yang sedang digunakan. 1 kanal SDCCH untuk membawa data persinyalan yang mengikuti hubungan antara ponsel dengan BTS sebelum pemberian TCH. serta disediakan $14 \mathrm{TCH}$ untuk menampung panggilan yang terjadi.

Terdapat 14 TCH atau $n=14$ sehingga intensitas trafik yang didapat sebesar 8,20 Erlang 
(dilihat dari tabel Erlang). Nilai tersebut merupakan kapasitas panggilan maksimum yang ditampung.

Untuk cell yang memiliki 3 modul TRU, rincian asumsi konfigurasi pengkanalannya adalah sebagai berikut :

$$
\begin{aligned}
1 \mathrm{TRU} & =8 \text { timeslot } \\
3 \mathrm{TRU} & =3 \times 8 \text { timeslot } \\
& =24 \text { timeslot }
\end{aligned}
$$

Konfigurasi 3 TRU ini menyediakan 1 kanal untuk BCCH, 1 kanal untuk SDCCH dan 22 kanal TCH untuk layanan voice. $22 \mathrm{TCH}$ atau $\mathrm{n}=22$ memiliki intensitas trafik sebesar 14,9 Erlang.

Adapun cell yang memiliki 4 modul TRU, berikut uraian pengkanalannya:

$$
\begin{aligned}
& 1 \mathrm{TRU}= 8 \text { timeslot } \\
& 4 \mathrm{TRU}=4 \times 8 \text { timeslot } \\
&=32 \text { timeslot } \rightarrow 30 \mathrm{TCH} \\
& 1 \mathrm{BCCH} \\
& 1 \mathrm{SDCCH}
\end{aligned}
$$

\section{$1 \mathrm{SDCCH}$}

Untuk konfigurasi 4 TRU memiliki 32 kanal yang 1 kanal BCCH untuk broadcast, 1 kanal SDCCH untuk menyediakan kanal TCH. Serta 30 kanal TCH untuk melayani panggilan. $30 \mathrm{TCH}$ atau $\mathrm{n}=30$ yaitu memiliki intensitas trafik 21,9 Erlang.

Besarnya intensitas trafik tersebut merupakan besarnya jumlah maksimal panggilan yang tertampung sehingga apabila dalam intensitas trafik perhari memiliki nilai yang lebih besar daripada nilai intensitas trafik pada GoS yang ditawarkan (2\%) maka pada kondisi demikian akan terjadi congestion. Traffic congestion inilah yang menyebabkan blocking panggilan.

\subsection{Kondisi TCH Saat Terjadi Traffic Congestion/ Sebelum TRU Upgrading}

\section{BTS Grendeng}

Site Grendeng atau BTS Grendeng adalah site yang terdiri atas 3 sektor/cell yaitu cell Grendeng 1, cell Grendeng 2, dan cell Grendeng 3. Seperti yang telah diuraikan pada pembahasan sebelumnya, bahwa cell yang menggunakan 2 modul TRU memiliki intensitas trafik maksimal (dengan GoS 2\%) adalah sebesar 8,20 Erlang inilah kondisi yang terjadi pada cell Grendeng 1.

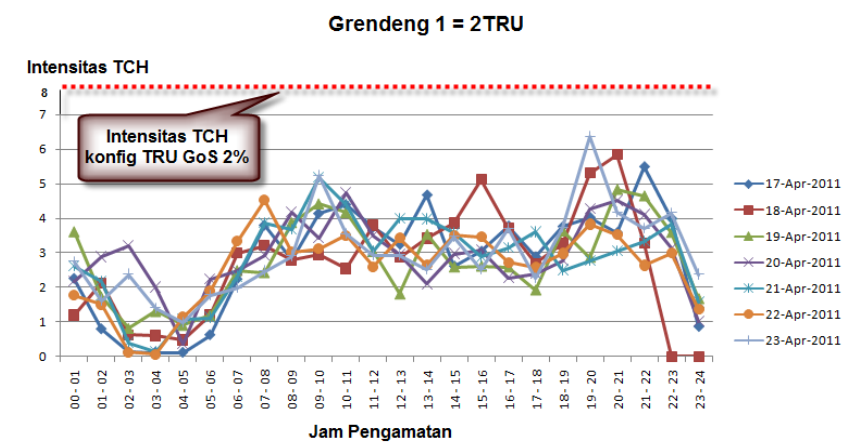

Gambar 3. Trafik pelanggan Grendeng 1

Apabila diambil dari data dan digambarkan seperti gambar 3 dapat dilihat bahwa intensitas trafik rerata dalam satu minggu kurang dari 8,20 Erlang. Dengan hal demikian maka dapat dikatakan bahwa pada kondisi cell ini tidak mengalami traffic congestion atau kondisi ideal.

Untuk cell Grendeng 2 jika dilhat dari volume traffic channel rerata selama satu minggu bernilai 16,66857 Erlang. Untuk lebih jelasnya terlihat pada grafik perjam harian selama satu minggu pada gambar 4 . 


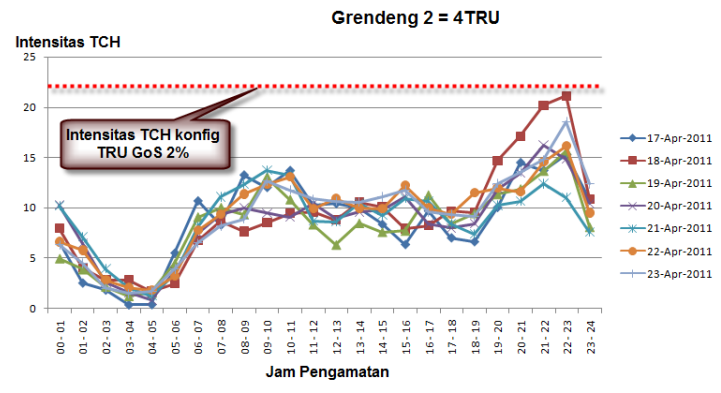

Gambar 4. Trafik pelanggan Grendeng 2

Trafik pelanggan pada cell ini masih dibawah dari batas intensitas trafiknya. Hal ini disebabkan konfigurasi cell tersebut adalah 4 TRU yang mana 4 TRU memiliki intensitas trafik sebanyak 21,9 Erlang. Artinya, 4 TRU tersebut mampu menangani semua volume trafik yang tertampung. Dengan kondisi demikian maka cell Grendeng 2 ini dinyatakan tidak mengalami traffic congestion.

Kondisi yang berbeda terjadi pada cell Grendeng 3. Cell ini menggunakan konfigurasi 3 TRU yang memiliki intensitas trafik sebesar 14,9 Erlang. Ditunjukan pada gambar 3.4, bahwa pada pukul 00.00 sampai dengan 06.00 WIB masih dalam kapasitas trafik yang disediakan TRU, namun pada sektar pukul 07.00 WIB terjadi kenaikan trafik yang cukup tinggi hingga melebihi kapasitasnya. Kondisi trafik pelanggan mengalami penurunan kembali pada pukul 11.00 hingga pukul 17.00 WIB. Rata- rata trafik tertinggi berada pada pukul 22.00-23.00 WIB.

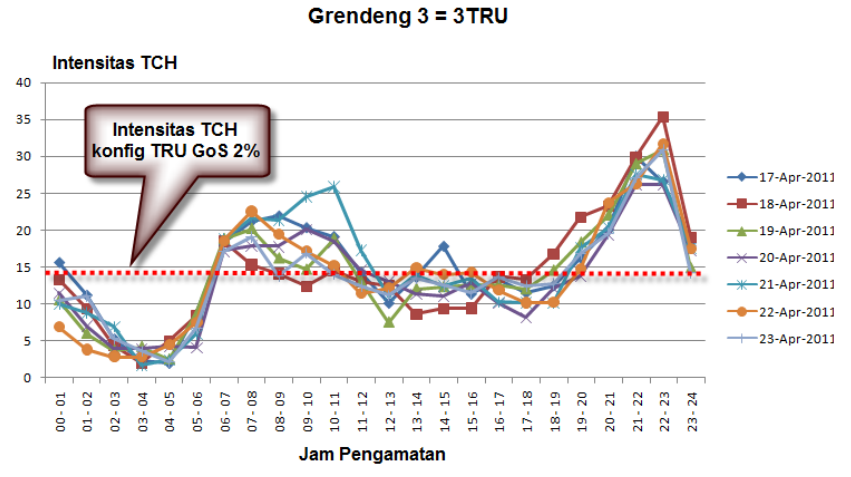

Gambar 5. Trafik pelanggan Grendeng 3

\section{BTS Pabuaran}

Site Pabuaran ini terdiri atas 3 sektor atau cell yang diberi sebutan Pabuaran 1, Pabuaran 2, dan Pabuaran 3. Cell Pabuaran 1 memiliki konfigurasi 3 TRU yang artinya memiliki intensitas trafik kanal TCH sebesar 14,9 Erlang. Pada cell ini trafik pelanggan tertinggi adalah sebesar 12,81 Erlang dan jika dilihat pada gambar 6, trafik pelanggan yang tertinggi masih berada dibawah kapasitas maksimum dari konfigurasi yang digunakan maka artinya pada cell pabuaran ini tidak terjadi traffic congestion.

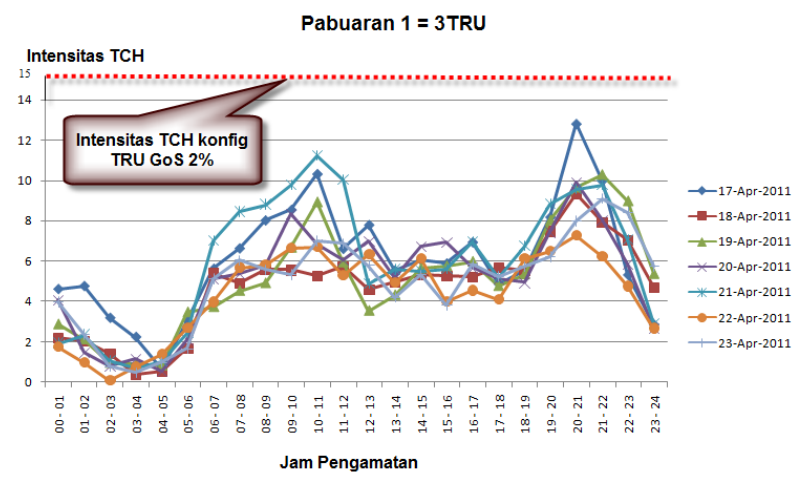

Gambar 6. Trafik Pelanggan Pabuaran 1 


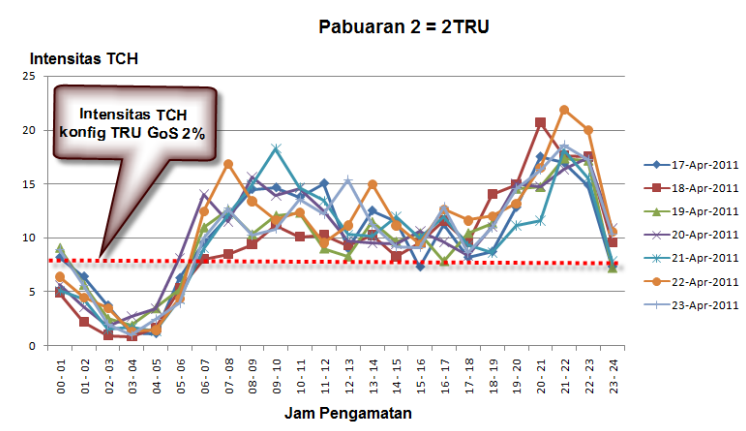

Gambar 7. Trafik Pelanggan Pabuaran 2

Perhatikan gambar 7, terlihat bahwa trafik pelanggan pada cell Pabuaran2 ini hampir sama dengan trafik pelanggan pada cell yang dibahas sebelumnya. Perbedaan yang jelas nampak pada batas kapasitas konfigurasi TRU yang digunakan. Cell Pabuaran 2 menggunakan konfigurasi 2 TRU dimana kapastitas trafik dibatasi sebesar 8,2 Erlang (sesuai ketetapan GoS 2\%). Dalam kondisi trafik pelanggan yang besarnya diatas kapasitas maksimum TCH dari TRU yang digunakan maka pada cell ini diperlukan TRU Upgrading.

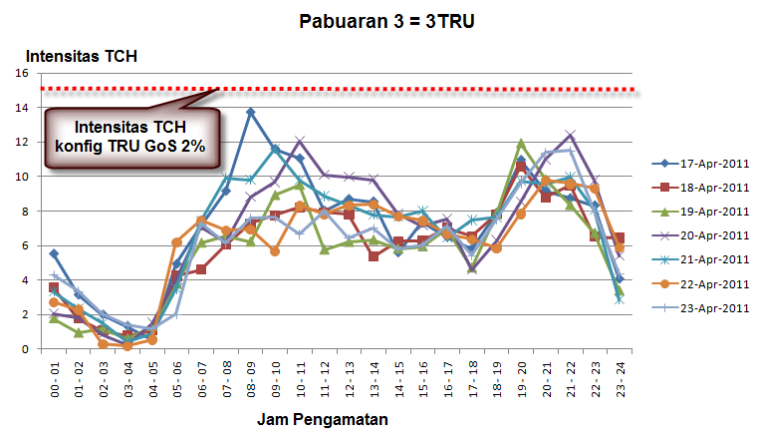

Grafik 8. Trafik Pelanggan Pabuaran3

Konfigurasi TRU cell Pabuaran 3 sama dengan konfigurasi TRU pada cell Pabuaran 1. Sama konfigurasinya maka akan sama pula kapasitas maksimum TCH yang ditampung oleh cell ini ( 3 TRU $=14,9$ Erlang). Berdasarkan data yang didapat serta ditunjukan oleh gambar
8, nilai rerata dari cell ini adalah sebesar 11,64 Erlang dan untuk peak traffic terjadi pada tanggal 17 April 2011 pukul 08.00-09.00 yaitu sebesar 13,73 Erlang. Dengan demikian pada cell ini tidak terjadi traffic congestion.

\section{BTS Unsoed}

Sama halnya dengan BTS atau site-site lainnya dalam pembahasan penelitian ini. Site Unsoed juga terdiri dari 3 cell yaitu cell Unsoed 1, Unsoed 2, Unsoed 3. Pada seluruh cell dalam site ini memiliki konfigurasi yang sama yaitu sebanyak 3 TRU dengan kapasitas maksimum 14,90 Erlang. Namun perilaku pelanggan pada masing-masing cell berbeda.

Untuk Unsoed 1 trafik pelanggan rerata dalam pengamatan perjam selama satu minggu adalah sebesar 35,34143 Erlang. Dalam cell Unsoed 1 ini jelas terjadi traffic congestion. Perilaku pelanggan pada cell Unsoed 2, dan cell Unsoed 3 hampir sama. Pada Unsoed 2, rerata TCH sebesar 13,70857 Erlang, sedang peack traffic daily-nya sebesar 14,06 Erlang yang terjadi 20 April 2011 pukul 08.00-09.00 WIB serta busy hour rata-rata terjadi pada jam 08.00 09.00 WIB. Untuk rerata TCH Unsoed 3 adalah sebesar 14,35 Erlang dan peack traffic sebesar 14.87 Erlang yang terjadi pada 22 April 2011 pukul 14.00-15.00 WIB. Kesamaan kedua cell ini adalah jumlah intensitas trafik pelanggan hampir memenuhi batas kapasitas dari konfigurasi TRU, namun kedua cell ini belum terlalu dibutuhkan TRU Upgrading. 


\subsection{Kondisi TCH Kondisi TCH Setelah Dilakukan TRU Upgrading}

\section{BTS Grendeng}

Untuk menangani trafik pelanggan yang tidak tertampung pada suatu cell maka dilakukan penanganan yang disebut TRU upgrading. TRU Upgrading ini dilakukan dengan dasar trafik pelanggan yang berlaku dalam satu cell tersebut. Dilakukan upgrade/penambahan perangkat TRU pada cell Grendeng3. Yaitu yang awalnya memiliki konfigurasi 3 TRU menjadi 4 TRU, atau dengan kata lain penambahan kapasitas kanal TCH juga yang awalnya 13,9 Erlang menjadi 21,9 Erlang.

Setelah dilakukan TRU upgrading trafik pelanggan masih terus diamati selama 1 minggu penelitian. Berdasarkan data pengamatan terlihat bahwa trafik pelanggan hampir sama dengan yang sebelum di upgrade. Tidak semua trafik pelanggan dapat tertampung dengan penambahan TRU terutama peak traffic dalam cell ini. Untuk cell Grendeng 1, dan Grendeng 2 tidak dilakukan TRU upgrading karena trafik pelanggan masih dibawah dari kapasitas maksimum TRU.

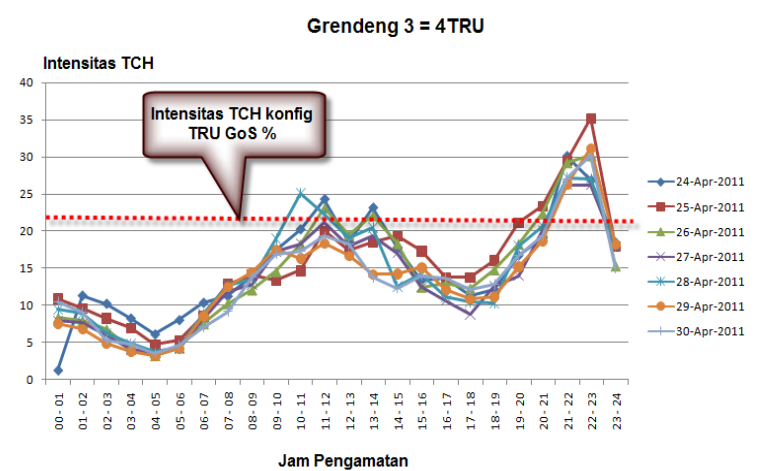

Gambar 9. Trafik Pelanggan Grendeng3

\section{BTS Pabuaran}

Pada site ini cell yang di tetap dengan konfigurasinya adalah cell Pabuaran1, dan cell Pabuaran 3. Ketiganya memiliki trafik pelanggan yang rata-rata dalam pengamatan ini masih dibawah dari kapasitas makasimum penggunaan TRU. Sedangkan, yang di upgrade adalah cell Pabuaran 2 dengan awal konfigurasi 2 TRU intensitas trafik sebesar 8,20 Erlang menjadi 4TRU intensitas trafik sebesar 21,9 Erlang. Trafik pelanggan hampir melampaui batas kapasitas yang disediakan, hal ini dapat dilihat pada peak traffic dari cell Pabuaran 2 yang bernilai 21,56 Erlang.

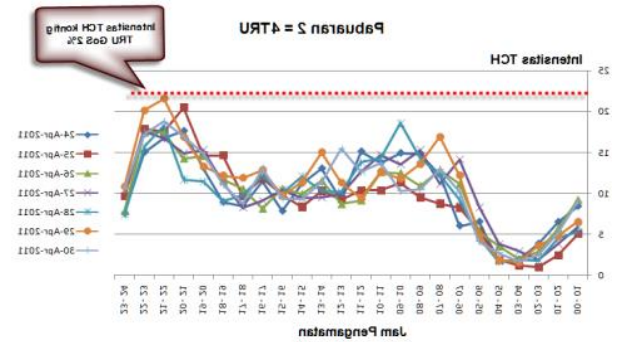

Gambar 10. Trafik Pelanggan Pabuaran 2

\section{BTS Unsoed}

Unsoed adalah site yang paling padat trafik penggunanya. Terlihat pada grafik cellcellnya. Grafiknya rata-rata stabil pada sekitar jam 07.00 hingga pukul 23.00 WIB. Meskipun trafik pelanggannya hampir memenuhi kapasitas maksimum dari konfigurasinya masing-masing, pada cell Unsoed 2, dan Unsoed 3 tidak dilakukan TRU upgrading hal ini dikarenakan batas kapasitas TRU masih dapat menampung seluruh trafik pelanggan pada cell-cell ini 


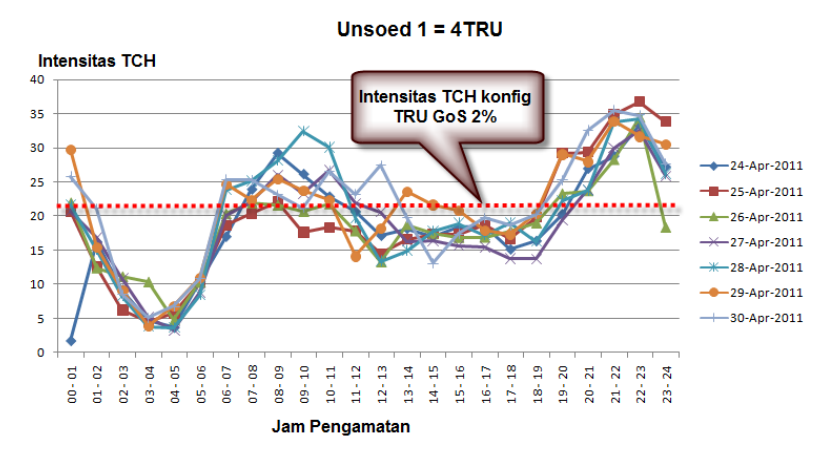

Gambar 11. Trafik Pelanggan Unsoed1

Cell pada site yang akan dilakukan TRU upgrading adalah cell Unsoed 1, dimana awalnya menggunakan 3 TRU diupgrade menjadi 4 TRU. nampaknya jika dilihat melalui gambar . Masih belum bisa menangani seluruh trafik pelanggan seluruhnya pada peak traffic busy hour.

\subsection{Konfigurasi BTS Sebelum dan Sesudah TRU Upgrading}

Tabel 2. Kondisi konfigurasi BTS sebelum dan sesudah TRU Upgrading

\begin{tabular}{|c|l|r|c|}
\hline \multirow{4}{*}{ Site } & Cell & $\begin{array}{r}\text { Sebelum } \\
\text { Upgrading }\end{array}$ & $\begin{array}{r}\text { Sesudah } \\
\text { Upgrading }\end{array}$ \\
\hline \multirow{4}{*}{ Grendeng } & Grendeng 1 & 2 & 2 \\
\cline { 2 - 4 } & Grendeng 2 & 4 & 4 \\
\cline { 2 - 4 } & Grendeng 3 & 3 & 4 \\
\hline \multirow{3}{*}{ Pabuaran } & Pabuaran 1 & 3 & 3 \\
\cline { 2 - 4 } & Pabuaran 2 & 2 & 4 \\
\cline { 2 - 4 } & Pabuaran 3 & 3 & 3 \\
\hline \multirow{3}{*}{ Unsoed } & Unsoed 1 & 3 & 4 \\
\cline { 2 - 4 } & Unsoed 2 & 3 & 3 \\
\cline { 2 - 4 } & Unsoed 3 & 3 & 3 \\
\hline
\end{tabular}

Pada Tabel 2 menunjukan kondisi masingmasing BTS (sebelum dan sesudah diterapkan metode TRU upgrading). Ketiga BTS ini memiliki kondisi yang berbeda hal ini disebabkan oleh intensitas trafik pelanggan yang pada setiap cell memiliki perilaku pelanggan yang berbeda-beda. Biasanya pada cell yang pada awalnya memiliki konfigurasi 4 buah TRU, sudah dilakukan TRU upgrading sebelum penelitian ini dilakukan atau memang digunakan TRU tersebut dikarenakan berdasarkan data pelanggan yang mengalami kejenuhan tinggi.

\subsection{Analisis Sesudah dan Sebelum Penerapan TRU Upgrading}

Dari hasil pengamatan terlihat bahwa salah satu cell dari masing-masing site yang diteliti mengalami traffic congestion. Seperti yang telah dijabarkan pada bab sebelumnya kondisi traffic congestion ini adalah kondisi dari cell yang memiliki nilai kapasitas pelanggannya melebihi intensitas trafik yang dimilki oleh konfigurasi TRU. Apabila terjadi kondisi traffic congestion seperti ini diperlukan TRU upgrading. Yaitu penambahan konfigurasi TRU sesuai dengan banyaknya trafik yang diduduki pelanggan. Di Indosat TRU yang digunakan adalah TRU dengan 1 TRX dan setiap satu cellnya digunakan maksimal 4 TRU. Jadi untuk satu site dengan konfigurasi maksimal adalah sebanyak 12 TRU.

TRU upgrading dilakukan berdasarkan data pengamatan selama 1 minggu. Instalasi TRU dilakukan selama 15 menit pada tanggal 24 April jam 00.00 WIB. TRU Upgrading ini dapat menambah kapasitas kanal suatu cell, untuk keefektifan penerapan metode ini berdasarkan 
pada trafik pelanggan cell tersebut. Dengan kata lain keefektifan penerapan ini tergantung pada perilaku pelanggan setiap cellnya. Untuk Pabuaran 2, metode ini sangat efektif terbukti dengan nilai blocking mencapai $0 \%$. Sedangkan kisaran penurunan bloking sebesar 40-44\% untuk cell Unsoed1 dan Grendeng3 karena pada cell ini mengcover area padat penduduk (berdasarkan peta lokasi)

\section{KESIMPULAN DAN SARAN}

\subsection{Kesimpulan}

Berdasarkan hasil analisis, dapat diambil kesimpulan diantaranya:

1. TRU Upgrading diterapkan pada cell Grendeng 3, Pabuaran 2, dan cell Unsoed 1.

2. Cell Grendeng 3 dan cell Unsoed 1 memiliki konfigurasi awal 3TRU kemudian dilakukan upgrade menjadi 4TRU. Untuk cell Pabuaran 2 konfigurasi awal 2 TRU menjadi 4 TRU.

3. Setelah dilakukan upgrade TRU pada cell Unsoed1 dan Grendeng 3 masih terjadi traffic congestion. Meskipun demikian Unsoed 1 dan Grendeng 3 mengalami penurunan bloking sekitar $40 \%$.

4. Untuk cell Pabuaran TRU Upgrading sangat efektif diterapkan, blocking menjadi $0 \%$.

5. Kelebihan TRU Upgrading terletas pada penambahan kapasitas kanal $\mathrm{TCH}$, kekurangannya saat TRU telah mencapai batas maksimal dan masih terjadi traffic congestion maka masih akan terjadi blocking pada cell yang bersangkutan.

\subsection{Saran}

1. Pengembangan tugas akhir dapat berupa simulasi perhitungan trafik pelanggan terhadap jumlah intensitas trafik konfigurasi TRU.

2. Digunakan modul TRU dengan menggunakan 4TRX atau lebih (disebut teknologi high capacity) agar trafik pelanggan tidak terlalu jenuh.

\section{DAFTAR PUSTAKA}

[1] Anonymous. Radio Access Network $(R A N) . \quad$ PT TELEKOMUNIKASI INDONESIA, Tbk.

[2] Anonymous. Dasar GSM 900/1800 buku II. TELKOM

[3] Hikmaturokhman, Alfin. 2006. Diktat Kuliah Mata Kuliah: Teknik Seluler. Akatel Purwokerto. Purwokerto.

[4] Kurniawan Usman, Uke dkk. 2008. Konsep Teknologi Seluler. PT. Informatika. Bandung.

[5] Kurniawan Usman, Uke dkk. 2010. Pengantar Ilmu Telekomunikasi. PT Informatika. Bandung.

[6] Mulyanta, Edi S. 2003. Kupas Tuntas Telepon Seluler Anda Ed-III. ANDI : Yogyakarta

[7] Puspita Dewi, Riana. 2011. Analisis Optimasi Kapasitas Trafik Dengan Multiband Cell (MBC) Pada Jaringan GSM Di PT. Xl Axiata, Tbk. Purwokerto. Akatel Sandhy Putra Purwokerto. Purwokerto. 
[8] Setyadillah, Febry. 2010.Optimalisasi Kapasitas Trafik dengan Transceiver Group Synchronization di PT. XL AXIATA, Tbk Purwokerto. Akatel Sandhy Putra Purwokerto. Purwokerto.

[9] Setyanto, Budi. Dasar-dasar Telekomunikasi Teknik Modern. 2010. PT. Sakti Umbulharjo. Yogyakarta

[10] Sunomo. 2004. Pengantar Sistem Komunikasi Nirkabel. PT. Grasindo. Jakarta.

[11] Syadam, Gouzali. 2005. Teknologi Telekomunikasi Perkembangan dan Aplikasi. Alfabeta : Bandung

[12] Ulva T Wello, Andi. 2009. Analisis Performansi Pada Jaringan GSM 900/1800 di Area Purwokerto Studi Kasus di PT. Excelcomindo Pratama Purwokerto. Akatel Sandhy Putra Purwokerto. Purwokerto.

[13] Ulya, Karimatul. 2011. Analisis Optimasi Kapasitas Sel Gsm Dengan Cell Splitting Studi Kasus Di PT Xl Axiata Purwokerto. Akatel Sandhy Putra Purwokerto. Purwokerto.

[14] Witjaksono, Bogi, Hanuranto,AT. 2000. Diktat Mata Kuliah Rekayasa Trafik. Sekolah Tinggi Teknologi Telkom Bandung. Bandung. 